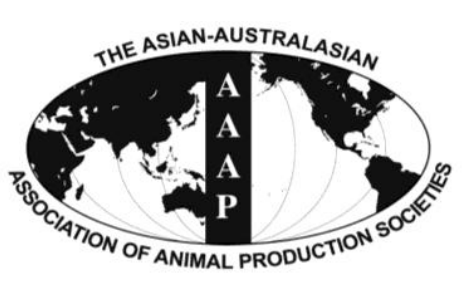

Open Access

Asian Australas. J. Anim. Sci.

Vol. 27, No. 8 : 1069-1074 August 2014

http://dx.doi.org/10.5713/ajas.2013.13289

pISSN 1011-2367 elSSN 1976-5517

\title{
Selection and Crossbreeding in Relation to Plumage Color Inheritance in Three Chinese Egg Type Duck Breeds (Anas Platyrhynchos)
}

\author{
R. L. Lin, H. P. Chen, R. Rouvier ${ }^{1}$, and J. P. Poivey ${ }^{2, *}$ \\ Fujian Longyan Shan Ma Duck Station, Longyan,364000 China
}

\begin{abstract}
In China and South East Asia, the duck (common duck) is important in egg production for human consumption. Plumage color is a breed characteristic and of economic importance, together with egg production. Our aim in this study was to investigate the inheritance of plumage color in three Chinese indigenous egg-type duck breeds, Shan Ma (S), Putian White (F) and Putian black $(\mathrm{P})$, and some of their crossbreds. These three breeds have different plumage color and are used in crossbreeding. The crossbred laying ducks $\mathrm{F} \times(\mathrm{P} \times \mathrm{S})$ and $\mathrm{F} \times(\mathrm{S} \times \mathrm{P})$ showed highly improved laying ability but heterogeneous plumage color. Genotypes at four relevant loci were investigated by studying down color and pattern in ducklings after crossbreeding. $\mathrm{F}_{1}$ ducklings from the matings $\mathrm{F} \times \mathrm{S}$ and $\mathrm{S} \times \mathrm{F}, \mathrm{P} \times \mathrm{S}$, and $\mathrm{S} \times \mathrm{P}$ were classified into four classes of plumage color (the Shan Ma plumage color, black, white, or multicolored) over three generations. Parents were selected for the Shan Ma plumage color of their progeny. In the fourth generation, $\mathrm{P}$ male and $\mathrm{P}$ female ducks were selected according to the frequency of the desired class of plumage color (Shan Ma) of their F1 progeny to obtain the so-called "Brown Putian Ma duck". The Shan Ma duck genotype was identified as having the restricted mallard color pattern $\left(M^{R} M^{R}\right)$, full expression of any of the patterns or colors (CC), no extended black (ee) and no brown dilution D (D). The Putian White genotype was recessive white (cc), no extended black (ee) and no brown dilution D (D). The Putian Black genotype exhibited full expression of extended black (E gene) and no brown dilution (CCEE D [D]). It was shown that $F \times S$ and $S \times F$ tests should be implemented to eliminate the recessive white $\mathrm{c}$ allele in the $\mathrm{S}$ line and the dominant extended black $\mathrm{E}$ allele in the $\mathrm{F}$ line. It was also shown that the Brown Putian Ma obtained from Putian Black, with no extended black genotype (ee), could be used to get rid of the black plumage (E gene) in the crossbred ducks. This could provide a solution for producing 3-way crossbred ducks Putian Whitex(Putian-Ma $\times$ Shan Ma) and Putian Whitex(Shan Ma×Putian-Ma), with the desired Shan Ma feather color. (Key Words: Egg-type Ducks, Plumage Color Inheritance, Crossbreeding, Selection)
\end{abstract}

\section{INTRODUCTION}

Duck eggs are an essential protein source in several Asian Countries, China being the greatest producer (Tai and Liu Tai, 2001). Duck egg production, which has increased in China, representing $14.9 \%$ of the total poultry egg

\footnotetext{
* Corresponding Author: J. P. Poivey. Tel: +33-0-4-67-59-39-07, Fax: +33-0-4-67-59-38-25, E-mail: poivey@ toulouse.inra.fr

1 Institut National de la Recherche Agronomique, Station d'Amélioration Génétique des Animaux, 31326 Castanet-Tolosan, France.

${ }^{2}$ Institut National de la Recherche Agronomique, UMR868 Systèmes d'Elevage Méditerranéens et Tropicaux, SELMET, 2 place Viala, F-34060 Montpellier, France.

Submitted May 22, 2013; Revised Sept. 16, 2013; Accepted Jan. 13, 2014
}

production in 2009 (Pingel, 2009), could be improved by selection and crossbreeding. However, a better understanding of plumage color genetics is necessary, due to the importance of obtaining homogeneous plumage color phenotypes. Shan Ma duck (S), Putian White duck (F) and Putian Black duck $(\mathrm{P})$ were selected to get the 3-way crossbred ducks $\mathrm{F} \times(\mathrm{P} \times \mathrm{S})$ and $\mathrm{F} \times(\mathrm{S} \times \mathrm{P})$. Egg production in these 3-breed crosses was greatly improved (Dong et al., 2011). However, several crossbred ducks were black feathered like Putian black, some were white feathered like Putian White and others showed the Shan Ma feather color. In order to meet consumer demand for the culled ducks for meat and farmer preference for homogeneous plumage color in laying ducks, our objective was to investigate the feasibility of selecting 3-way crossbred ducks for the Shan 
Ma plumage color.

Shan Ma and Putian Black ducks (Anas platyrhynchos) are egg-type duck breeds in Fujian. They are listed in the Fujian Province and State lists of protected species which constitute livestock and poultry genetic resources (Yiu et al., 1985; Xu and Chen, 2003). They belong to the 26 Chinese Indigenous duck breeds whose biodiversity has been revealed by microsatellite markers (Liu et al., 2008). Putian White Duck is a new line of egg-type ducks bred in the 1980s by Tan Junyi from the Institute of Animal Husbandry at the Fujian Academy of Agricultural Sciences. Putian White ducks have extended white plumage color and were obtained by selecting a mutation which appeared in Putian Black. Shan Ma is an egg-laying mini-breed showing light spotty to brown spotty plumage, yellow beak, reddish orange shanks and webs, and black toe nails. Putian Black drakes and ducks have extended black plumage color. They have black shanks with black webs and toe nails. Further investigation of the genetics of plumage color in these Chinese indigenous egg-type duck breeds seemed relevant.

A survey of plumage color inheritance in the common duck was compiled by Lancaster (1963, 1990). Nevertheless, as far as we know, nothing has been published about plumage color inheritance in the three duck breeds Putian White, Putian Black and Shan Ma and, except in Gong et al. (2010) for Liancheng White, in Chinese indigenous egg-type ducks in general. Crossbreeding $\mathrm{F} \times \mathrm{S}$, $\mathrm{S} \times \mathrm{F}$ and $\mathrm{P} \times \mathrm{S}, \mathrm{S} \times \mathrm{P}$ tests were carried out over three generations. Parents were selected for Shan Ma plumage color of the crossbred progeny. Genotypes for feather color were investigated at the relevant loci.

Hereafter we discuss the genetic mechanisms controlling plumage color in these three Chinese egg-type duck breeds and how a homogeneous plumage color was obtained in some of the crossbreds.

\section{MATERIALS AND METHODS}

\section{Ducks and experimental design}

The Lancaster surveys $(1963,1990)$ considered 11 loci (comprising 24 genes) which control plumage color in the common duck (Anas platyrhynchos). The gene descriptions were for common ducks of most of the breeds found in Great Britain and not for Chinese indigenous egg-type ducks. The Lancaster loci for duck plumage coloration and pattern were as follows: Restricted, mallard, dusky series $\left(\mathrm{M}^{\mathrm{R}}, \mathrm{M}, \mathrm{m}_{\mathrm{d}}\right)$; Dark phase, light phase, harlequin phase series (Li, li, li ${ }^{\mathrm{h}}$ ); Extended black (E); Recessive white (c); Three loci for sex-linked genes of dilution: Brown dilution (d), Blue dilution (Bl) and Buff dilution (bu). Dominant bib (S); Recessive bib (b); Runner pattern (R); white primaries (w).

Crosses and selections were therefore carried out to test the three Chinese breeds for plumage color genotypes. Reciprocal $\mathrm{F} \times \mathrm{S}$ and $\mathrm{S} \times \mathrm{F}, \mathrm{P} \times \mathrm{S}$, and $\mathrm{S} \times \mathrm{P}$ crosses were performed in 2008, 2009, and 2010. Each drake was mated with 12 female ducks. Matings were carried out in two successive batches separated by 10 days, using different drakes and the same female ducks. Each year 16 drakes and 8 groups of 12 females were tested per crossbreeding type. In 2009, six $\mathrm{P}$ drakes and six $\mathrm{S}$ drakes were used with 3 groups of 12 females for the $\mathrm{P} \times \mathrm{S}$ and $\mathrm{S} \times \mathrm{P}$ crossbreeding tests, respectively. One drake and 12 female ducks were alloted to separate pens with natural mating. Drakes and ducks were individually identified by wing and feet numbers. The ducks were individually caged during the evening and over-night to ensure accurate identification of the mother of any eggs laid. The eggs were collected every morning, individually identified and stored up to 15 days before egg set. Egg collecting was carried out for 30 days in each batch. Pedigree hatching was performed. The down color of one-day-old ducklings of each sex was individually recorded in one of four classes, namely ma, white, black or multicolored. Ma, white and black are the color and plumage pattern classes of Shan Ma, Putian White and Putian Black, respectively. Multicolored down indicates a non-defined duck breed or color pattern.

During the first year, the breeding drakes and ducks of each breed were randomly chosen within the breeds on the station. In the following years, the progeny of drakes and ducks which had been selected for the frequency of ma ducklings in their progeny were also included. Separate S, F, and P lines were established. In October 2010, each of four $\mathrm{P}$ drakes selected for the Shan Ma plumage color of their $\mathrm{P} \times \mathrm{S}$ progeny were mated with female $\mathrm{P}$ ducks selected for the Shan Ma plumage color of their $\mathrm{S} \times \mathrm{P}$ progeny.

\section{Statistical tests of the hypotheses}

The segregation ratio for the two alleles at a given locus was tested by comparing the observed frequencies at a probability of 0.5 , using the normal approximation of the binomial law of probability with large samples. In the same way, the genotypes ratio $1 / 3$ was tested by comparing the observed frequencies at a probability of 0.25 .

\section{RESULTS AND DISCUSSION}

Table 1 shows the evolution in the percentages of the Shan Ma plumage color (ma), white, black and multicolored classes over the years and generations. The $\mathrm{F} \times \mathrm{S}$ and $\mathrm{S} \times \mathrm{F}$ tests revealed a tremendous increase in ma and a decrease of black across the generations. No difference between the two sexes was observed. In $\mathrm{P} \times \mathrm{S}$ the ma percentage in sire progeny was either 0 or a positive value which was not significantly different from $50 \%$ according to a statistical $t$ test. In $\mathrm{S} \times \mathrm{P}$ the ma percentage in dam progeny was either 0 
Table 1. Crossbreeding tests for down color in one-day old ducklings: number $\mathrm{n}$ of ducklings, percent of ducklings in ma, white, black and multicolored classes in the years 2008, 2009, and 2010

\begin{tabular}{lcccccc}
\hline Mating & Year & Ducklings (n) & Ma (\%) & White (\%) & Black (\%) & Multicolored (\%) \\
\hline $\mathrm{F} \times \mathrm{S}$ & 2008 & 1,921 & 44.1 & 2.5 & 30.5 & 22.9 \\
$\mathrm{~F} \times \mathrm{S}$ & 2009 & 2,518 & 70.8 & 1.6 & 26.0 & 1.6 \\
$\mathrm{~F} \times \mathrm{S}$ & 2010 & 2,611 & 84.3 & 3.7 & 11.6 & 0.4 \\
$\mathrm{~S} \times \mathrm{F}$ & 2008 & 822 & 41.5 & 13.1 & 37.6 & 7.8 \\
$\mathrm{~S} \times \mathrm{F}$ & 2009 & 1,261 & 77.9 & 0.9 & 20.9 & 0.3 \\
$\mathrm{~S} \times \mathrm{F}$ & 2010 & 2,444 & 82.0 & 11.3 & 6.6 & 0.1 \\
$\mathrm{P} \times \mathrm{S}$ & 2008 & 1,226 & 19.2 & 0 & 80.4 & 0.4 \\
$\mathrm{P} \times \mathrm{S}$ & 2009 & 950 & 39.9 & 0 & 60.1 & 0 \\
$\mathrm{P} \times \mathrm{S}$ & 2010 & 2,821 & 22.8 & 0 & 77.2 & 0 \\
$\mathrm{~S} \times \mathrm{P}$ & 2008 & 1,125 & 10.6 & 0 & 89.4 & 0 \\
$\mathrm{~S} \times \mathrm{P}$ & 2009 & 689 & 13.8 & 0 & 0 & 0 \\
$\mathrm{~S} \times \mathrm{P}$ & 2010 & 1,814 & 32.7 & 0 & 67.3 & 0
\end{tabular}

$\mathrm{F} \times \mathrm{S}=$ Putian White $\times$ Shan $\mathrm{Ma} ; \mathrm{S} \times \mathrm{F}$ reciprocal cross. $\mathrm{P} \times \mathrm{S}=$ Putian Black $\times$ Shan $\mathrm{Ma}$; $\mathrm{S} \times \mathrm{P}$ reciprocal cross.

$\mathrm{Ma}=$ Duckling's down pattern and color similar to that of the Shan Ma duckling. Black = Duckling down of extended black color.

White $=$ Yellow down color and white adult plumage. Multicolored = Undefined color pattern.

or a positive value not significantly different from $50 \%$. The complementary color percentage was black. Table 2 gives the percentages of ma in the progeny of the four $\mathrm{P}$ sires mated with the $24 \mathrm{P}$ dams which had been selected. The ma percentage in $\mathrm{P} \times \mathrm{S}$ progeny of these $\mathrm{P}$ sires and $\mathrm{S} \times \mathrm{P}$ progeny of these $\mathrm{P}$ dams was not significantly different from $50 \%$. The complementary color was black. The percentage of ma in the progeny of these four $\mathrm{P}$ sires mated with these $24 \mathrm{P}$ dams was not significantly different from $25 \%$. The 78 ma progeny were called Brown Putian Ma.

A former crossbreeding experiment at Shan Ma duck station (Dong et al., 2011) had shown that the three-breed cross increased egg production in 500-day old female ducks by $11.8 \%$ for egg number and by an average of $22.4 \%$ for total egg weight, in comparison with the pure breeds. The average egg production for the three breeds Putian Black (296 eggs), Putian white (280 eggs) and Shan Ma (300 eggs) was 292 and the average total egg weight was 19.55 $\mathrm{kg}$. When the pure breeds were compared, egg production was significantly highest for Shan Ma. Crossbreeding of $\mathrm{S} \times \mathrm{P}$ and $\mathrm{P} \times \mathrm{S}, \mathrm{S} \times \mathrm{F}$, and $\mathrm{F} \times \mathrm{S}$ resulted in highly significant

Table 2. Ma color percentage (MA) in the progeny of 4 Putian Black sires and 24 dams Putian Black. For each sire, is given the number of dams (NDA), number of ducklings (NDU) number of ma (NMA) or black (NBL) ducklings

\begin{tabular}{lccccc}
\hline $\begin{array}{c}\text { Sire wing } \\
\mathrm{N}^{\circ}\end{array}$ & NDA & NDU & NMA & NBL & $\begin{array}{c}\text { MA } \\
(\%)\end{array}$ \\
\hline X204 & 4 & 53 & 11 & 42 & 20.75 \\
C394 & 7 & 108 & 23 & 85 & 21.30 \\
D542 & 5 & 67 & 15 & 52 & 22.40 \\
E345 & 8 & 109 & 29 & 80 & 26.61 \\
Total & 24 & 337 & 78 & 259 & 23.15 \\
\hline
\end{tabular}

$\mathrm{Ma}=$ Duckling's down pattern and color similar to that of the Shan $\mathrm{Ma}$ duckling.

Black = Duckling down of extended black color. effects of heterosis on egg number $(9.3 \%$ and $8.5 \%$ respectively), total weight of eggs laid $(11.7 \%$ and $12.8 \%$ respectively), and on the feed consumption to total egg weight ratio $(-8.0 \%$ and $-7 \%$ respectively).

Analysis of our data, based on the Lancaster references (1963, 1990), showed that 4 loci would need to be investigated to genotype the three breeds S, F, and P. The wild type alleles were present at the other loci where no segregation was observed. The genes for plumage color and pattern were determined from the description and classification of down color and pattern in one-day-old purebred and crossbred ducklings. The locus with the 3 alleles $\mathrm{M}^{\mathrm{R}}$ dominant to $\mathrm{M}$ which is dominant to $\mathrm{m}^{\mathrm{d}}$, which controls the color pattern, was first described by Jaap (1934). The M allele allows full expression of the wild plumage color pattern of the adult Mallard duck. Self-white plumage in the common duck corresponds to homozygosity for an autosomal recessive gene (c) (Jaap, 1933a). At that locus the dominant allele $\mathrm{C}$ allows full expression of any of the genes for pattern, color or dilution which are present. The recessive white allele when homozygous (cc) prevents the expression of color. The one-day-old ducklings had a yellow down color, yellow bill, shank and web. This fitted the description of down color in Putian White ducklings. The $\mathrm{C}$ locus controls melanin synthesis, the $\mathrm{C}$ allele and cc genotype respectively permitting and preventing melanin synthesis. Gong et al. (2010) observed grey phenotypes in the F1 generation from a cross between two white plumage duck varieties, i.e., white Kaiya (which is a crossbred between a Pekin drake and a White Tsaiya duck) and Liancheng White. They reported, for the first time, a new autosomal locus $\mathrm{T}$ which governs melanin transfer to the feathers in a Chinese indigenous duck breed, Liancheng White (Xu and Chen, 2003). Liancheng White (genotype $\mathrm{CCtt}$ ) has pure white plumage but black beak, and gray 
black or black shank and webs. Recently Li et al. (2012) used ducks from the F2 population of the previous experiment (cross between white Kaiya and white Liancheng) to identify the genes involved in the formation of white and black plumage in ducks. RNA from white and black feather bulbs were analysed using RNA-Seq. A number of genes controlling melanogenesis were found to show differential expression between the two types of feather bulbs. At the locus for extended black (E), the E allele, which is dominant to the e allele, causes solid black pigment to be laid down in all areas except those controlled by genes for white spotting. It is epistatic against the $M^{R}, M$, and $\mathrm{m}^{\mathrm{d}}$ alleles but not against the cc genotype. The one-dayold ducklings have black colored down, and black bill, shank and web. The Putian Black ducklings fitted that color description. At the locus for Brown dilution there are two sex-linked alleles D, d, with D dominant to recessive d. Recessive $\mathrm{d}$ is primarily a diluter of black pigment (Lancaster, 1963). All black areas and black lacing are diluted to dark chocolate brown. The three breeds S, F and $\mathrm{P}$ were genotyped D (D) at the locus for brown dilution.

It was observed that, in one-day-old Shan Ma ducklings, the area of dark pigment on the dorsal surface was confined to patches on the head and tail. The rest of the dorsal surface was yellow with a dark undercolor. The ventral surface was yellowish with a dark undercolor. This corresponded to an effect of the gene for restricted mallard pattern $\left(\mathrm{M}^{\mathrm{R}}\right)$. The genotype of Shan Ma duck was determined as being $\mathrm{M}^{\mathrm{R}} \mathrm{M}^{\mathrm{R}} \mathrm{CCeeD}$ (D). Nevertheless the presence of white in the breast region of some ducklings was observed, which is characteristic of light phase ducklings (Jaap, 1933b; Lancaster, 1963). At the dark phase autosomal locus $\mathrm{Li}$, the dominant dark phase allele $\mathrm{Li}$ allows full expression of any one of the three mallard alleles, the light phase li allele when homozygous lili lightens the plumage color of the adult female duck and increases sex dimorphism of the plumage pattern in the males, and a third harlequin phase $1 \mathrm{i}^{\mathrm{h}}$ allele has also been reported (Lancaster, 1963). The presumed lili genotype for Shan Ma duck needs further investigation.

Data from 2010 were then used to determine the genotypes for feather color and the effects of selection. In the $\mathrm{F} \times \mathrm{S}$ cross, four out of $12 \mathrm{~F}$ sires produced ma and black color progeny with all the mated $\mathrm{S}$ females. Table 3 gives the ma and black phenotypes in the $\mathrm{F} \times \mathrm{S}$ crossbred offspring of these 4 sires and the significance level for t tests, corresponding to a hypothesized expected ma/black ratio of $1: 1$. The observed frequencies of the ma phenotype were compared at the probability $\mathrm{p}=50 \%$. Three female families which included ma, black and multicolored progeny were discarded. Five female families which included ma, black and white were also discarded because the recessive white gene, when homozygous, is epistatic over all other color loci. For three sires, the tests of departure from the hypothesis were not significant and so the hypothesis of a $\mathrm{ma} / \mathrm{black}$ ratio of 1:1 was retained. For one sire the test was highly significant with a ma color frequency of $61.6 \%$, which was explained by the occurrence of one dam family with only ma color progeny (17 ducklings). In total, the frequencies of ma and black color progeny for these $4 \mathrm{~F}$ sires were $51.7 \%$ and $48.3 \%$ respectively. These frequencies were not significantly different from $50 \%$ and the hypothesis of a ma/black ratio of 1:1 was retained. The genotypes of these $4 \mathrm{~F}$ sires were assumed to be ccEe because half of the genes transmitted from the extended black locus to their progeny were the $\mathrm{E}$ allele and half were the e allele, while the genotypes of the mated $\mathrm{S}$ females included in the analysis were CCee (Table 3). The other 12 F sires mated with the $\mathrm{S}$ females produced $100 \%$ ma color progeny with all the mated $S$ females except 11 female ducks, which were discarded. Their genotype was supposed to be ccee and the putative genotype of the mated $\mathrm{S}$ females was CCee. The eleven $\mathrm{S}$ female ducks produced ma and white progeny with respective frequencies of $60.9 \%$ and $39.1 \%$. Although the frequency of white was significantly less than $50 \%$, their presumed genotype was Ccee.

Conversely, in the $\mathrm{S} \times \mathrm{F}$ cross, four $\mathrm{S}$ sires produced ma and white progeny with all the mated $F$ females. Six of these $\mathrm{F}$ females also produced 22 black ducklings in total and one female produced two multicolored ducklings. Table 4 gives the white and non-white (ma+black+multicolored) phenotypes for feather coloration in $\mathrm{S} \times \mathrm{F}$ crossbred

Table 3. Ma and black phenotypes of feather coloration in $\mathrm{F} \times \mathrm{S}$ offspring from four $\mathrm{F}$ sires, with $\mathrm{t}$ tests

\begin{tabular}{lccccccc}
\hline $\begin{array}{c}\text { Combinations of } \\
\text { putative genotypes }\end{array}$ & $\begin{array}{c}\text { Types of } \\
\text { offspring }\end{array}$ & $\begin{array}{c}\text { Expected ratios } \\
\text { of ma vs black }\end{array}$ & $\begin{array}{c}\text { Number of full-sibs } \\
\text { families observed }\end{array}$ & $\begin{array}{c}\text { Observed numbers } \\
\text { of ma vs black }\end{array}$ & Ma (\%) & t-value & Significance \\
\hline ccEexCCee & F1 & $1: 1$ & 10 & $83: 83$ & 50.0 & 0.0 & NS \\
ccEexCCee & F1 & $1: 1$ & 11 & $50: 66$ & 43.1 & 1.5 & NS \\
ccEexCCee & F1 & $1: 1$ & 9 & $60: 64$ & 48.4 & 0.4 & NS \\
ccEexCCee & F1 & $1: 1$ & 10 & $106: 66$ & 61.6 & 3.0 & HS \\
Total & & & & $299: 279$ & 51.7 & 0.8 & NS \\
\hline
\end{tabular}

F×S = Putian WhitexShan Ma.

$\mathrm{Ma}=$ Duckling's down pattern and color similar to that of the Shan Ma duckling. Black = Duckling down of extended black color

$\mathrm{t}$ value, value of standardized normal deviate of observed ma frequency (ma $\%$ ) to probability $\mathrm{p}=50 \%$.

NS, not significant ( $\mathrm{p}>0.05)$; HS, highly significant $(\mathrm{p}<0.01)$. 
offspring from these four $\mathrm{S}$ sires, together with $\mathrm{t}$ tests. The putative genotype combinations which were tested were Cceexccee ( $50 \%$ of white expected in the sire progeny) or CceexccEe. With that second hypothesis, the expected progeny frequencies for a dam would be $50 \%$ white, $25 \%$ ma and $25 \%$ black. As the expected frequency of white was $50 \%$ there was no bias in the observed frequencies of white color in the sire progeny. The frequencies of white feather color were not significantly different from 0.5 for the progeny of one sire $(44.8 \%)$, were significantly different for one sire $(41.5 \%)$ and highly significantly different for the two other sires (37.2\% and 31.4\%). The hatchabilities (number of ducklings born alive/number of eggs set) were significantly lower for the two groups with the lowest frequencies of white plumage color, when compared with the two other groups $(70 \%$ vs $79 \%)$. One explanation for the lower than expected frequencies of white plumage color in these two groups could be a lower fertility of spermatozoa bringing the $\mathrm{c}$ allele as compared to the $\mathrm{C}$ allele, or a lower embryo viability of the cc genotypes than the genotypes $\mathrm{Cc}$. In total, the frequency of white for the four sires was $40.4 \%$, which was highly significantly lower than the expected value of $50 \%$. These $\mathrm{S}$ sires were genotyped Ccee because they transmitted the c allele to their offspring. The F dams were genotyped ccee if they gave no black progeny and ccEe if they produced at least one black progeny. Mating of the other $12 \mathrm{~S}$ sires with $\mathrm{F}$ females produced ma and no white progeny. These were genotyped CCee. Eighteen F females, which were mated with different males among these 12 sires, produced ma and black progeny, the frequencies of ma and black being $55 \%$ and $45 \%$ respectively. These frequencies are not significantly different from $50 \%$. These dams were genotyped ccEe because at the extended black locus, half of the ova were presumed to bring the $\mathrm{E}$ allele and the other half the e allele.

The E allele segregated in the Putian White line for which the genotypes were ccee or ccEe. The c allele segregated in the $\mathrm{S}$ line for which the genotypes were CCee or Ccee. The main effects of selection were to increase the frequency of the e allele and to decrease the frequency of the $\mathrm{E}$ allele in the $\mathrm{F}$ breed, and to decrease the frequency of the c allele in the $\mathrm{S}$ breed. We concluded that $\mathrm{F} \times \mathrm{S}$ and $\mathrm{S} \times \mathrm{F}$ crossbreeding tests would make it possible to eliminate the $\mathrm{E}$ extended black allele in the $\mathrm{F}$ breed and the $\mathrm{c}$ recessive white allele in the $\mathrm{S}$ breed.

The desired Putian White genotype was established as being cceeD (D) because in the $\mathrm{F} 1$ female duck $\mathrm{F} \times \mathrm{S}$ there is no brown dilution. $\mathrm{M}^{\mathrm{R}}$ is a dominant allele present in $\mathrm{S}$. It was difficult to ascertain the genotype of $\mathrm{F}$, at the locus controlling the plumage color pattern, from the crossbreeding tests. One way of determining the alleles at the locus controlling color pattern in the F breed, would be to perform $(\mathrm{F} \times \mathrm{S}) \times(\mathrm{F} \times \mathrm{S})$ crosses.

In the $\mathrm{P} \times \mathrm{S}$ cross, nine $\mathrm{P}$ sires produced only black $\mathrm{F} 1$ progeny and their genotypes were presumed to be CCEE, the $\mathrm{S}$ female genotypes being CCee. Seven $\mathrm{P}$ sires produced ma and black progeny. The ma frequencies varied from $43.1 \%$ to $54.1 \%$ between sires, with none of these frequencies being significantly different from $50 \%$, and the average ma frequency being $50.1 \%$. The genotypes of these sires were presumed to be CCEe. When they were mated with $\mathrm{S}$ female ducks, they were expected to transmit the $\mathrm{E}$ gene to half of their progeny and the e gene to the other half. In the $\mathrm{S} \times \mathrm{P}$ cross, 25 out of the 77 dams produced only black progeny, and were genotyped EE at the extended black locus. The others produced ma and black progeny, the average ma frequency being $50.4 \%$, which was not significantly different from $50 \%$. They were genotyped Ee at the extended black locus. The effect of selection measured in the $\mathrm{P}$ female was to increase the frequency of no extended black e allele from $10.6 \%$ in the first generation to $32.7 \%$ in the third generation (Table 1). Such evolution was not observed in the $\mathrm{P}$ sires for which the frequencies of the e allele over the three generations were $19.2 \%, 39.9 \%$, and $22.8 \%$ for the first, second and third generations, respectively (Table 1). Sampling of the $\mathrm{P}$ drakes in the 3rd generation included several males whose fathers were not selected after testing. As no white progeny were observed in the $\mathrm{P} \times \mathrm{S}$ and $\mathrm{S} \times \mathrm{P}$ crosses, it was assumed

Table 4. White and colored (ma+black+multicolored) phenotypes of feather coloration in $\mathrm{S} \times \mathrm{F}$ offspring from four $\mathrm{S}$ sires, with $\mathrm{t}$ tests

\begin{tabular}{lccccccc}
\hline $\begin{array}{c}\text { Combinations of } \\
\text { putative genotypes }\end{array}$ & $\begin{array}{c}\text { Types of } \\
\text { offspring }\end{array}$ & $\begin{array}{c}\text { Expected ratios of } \\
\text { white vs colored }\end{array}$ & $\begin{array}{c}\text { Number of full-sibs } \\
\text { families observed }\end{array}$ & $\begin{array}{c}\text { Observed numbers } \\
\text { of white vs. colored }\end{array}$ & White (\%) & t-value & Significance \\
\hline Cceexccee & F1 & $1: 1$ & 12 & $78: 96$ & 44.8 & 1.4 & NS \\
or & F1 & $1: 1$ & 12 & $78: 110$ & 41.5 & 2.3 & S \\
CceexccEe & F1 & $1: 1$ & 12 & $64: 108$ & 37.2 & 4.9 & HS \\
& F1 & $1: 1$ & 12 & $49: 107$ & 31.4 & 4.6 & HS \\
Total & & & & $269: 421$ & 40.4 & 5.2 & HS \\
\hline
\end{tabular}

$\mathrm{S} \times \mathrm{F}=$ Shan Ma×Putian White.

White $=$ Yellow down color and white adult plumage. $\mathrm{Ma}=$ Duckling's down pattern and color similar to that of the Shan Ma duckling.

Black $=$ Duckling down of extended black color. Multicolored $=$ Undefined color pattern.

$\mathrm{t}$ value, value of standardized normal deviate of observed white frequency (white $\%$ ) to probability $\mathrm{p}=50 \%$.

NS, not significant $(p>0.05)$; S, significant $(p<0.05)$; HS, highly significant $(p<0.01)$. 
that the recessive $\mathrm{c}$ gene was not segregating in the $\mathrm{P}$ breed (or was segregating at a very low frequency). The P breed genotypes were CCEED (D) or CCEeD (D).

After the third generation, four $\mathrm{P}$ sires and $24 \mathrm{P}$ dams, which had been selected because they produced ma and black progeny in the $\mathrm{P} \times \mathrm{S}$ and $\mathrm{S} \times \mathrm{P}$ crosses, were mated together. Assuming that their genotypes were $\mathrm{CC} \mathrm{Ee,} \mathrm{the}$ expected frequency of ee (no extended black) in their progeny would be $25 \%$. Table 2 shows that $23.15 \%$ of ducklings with a down color similar to Shan Ma were obtained, which is not significantly different from $25 \%$. The hypothesis of non-extended black homozygous ee genotypes at the extended black locus (E) in these 78 progeny was therefore accepted. As the ducklings' down color pattern was similar to that of the Shan Ma ducklings, Putian Black was assumed to carry the $\mathrm{M}^{\mathrm{R}}$ gene. The putative genotype of these 78 progeny, designated Brown Putian Ma would be $\mathrm{M}^{\mathrm{R}} \mathrm{M}^{\mathrm{R}} \mathrm{CCeeD}$ (D). By using Brown Putian Ma instead of Putian Black in the three breed crosses it should be possible to get rid of the black plumage color in crossbred ducks, but Brown Putian Ma now has to be extended and tested for egg production.

The genotypes for plumage color in three indigenous Chinese egg-type duck breeds were investigated in order to improve the frequency of Shan Ma plumage color in the three- breed crosses $\mathrm{F}(\mathrm{P} \times \mathrm{S})$ and $\mathrm{F}(\mathrm{S} \times \mathrm{P})$. For the first time, genotypes of plumage color at four main loci in these three Chinese egg-type ducks were established. Means of selecting the Shan Ma breed (S) to get rid of the epistatic white recessive $\mathrm{c}$ allele in this breed, and the Putian White (F) to eliminate the extended black dominant $\mathrm{E}$ allele in this breed, were demonstrated. A line for desired plumage color of three crossbred ducks, Brown Putian-Ma, is under construction and will be tested for egg production.

\section{REFERENCES}

Dong, T., R. L. Lin, and H. P. Chen. 2011. The selection of three lines Shanma duck with high egg production. Contemporary Animal Husbandry 3:38-40.

Gong, Y., Q. Yang, S. Li, Y. Feng, C. Gao, G. Tu, and X. Peng. 2010. Grey plumage coloration in the duck is genetically determined by the alleles on two different, interacting loci. Anim. Genet. 41:105-108.

Jaap, R. G. 1933a. Inheritance of white spotting in ducks. Poult. Sci. 12:233-241.

Jaap, R. G. 1933b. Light phase mallard ducks. J. Hered. 24:467472.

Jaap, R. G. 1934. Alleles of the Mallard plumage pattern in ducks. Genetics 19:310-322.

Lancaster, F. M. 1963. The inheritance of plumage color in the common duck (Anas Platyrhynchos Linne). Bibliographia Genetica XIX, 's-Gravenhage: M. Nijhoff, The Hague, The Netherlands, pp.317-404.

Lancaster, F. M. 1990. Mutations and major variants in domestic ducks. In: Poultry Breeding and Genetics (Ed. R. D. Crawford). Elsevier, Amsterdam, The Netherlands. Chapter 16. pp. 381387.

Li, S., C. Wang, W. Yu, S. Zhao, and Y. Gong. 2012. Identification of genes related to White and Black Plumage formation by RNA-seq from White and Black feather bulbs in ducks. PloS ONE 7(5):e36592.

Liu, W., Z. C. Hou, L. J. Qu, Y. H. Huang, J. F. Yao, N. Li, and N. Yang. 2008. Population structure and biodiversity of Chinese indigenous duck breeds revealed by 15 microsatellite markers. Asian Australas. J. Anim. Sci. 21:314-319.

Pingel, H. 2009. Waterfowl production for food security. Conference at the 4th World Waterfowl conference, Thrissur, India, $6 \mathrm{p}$.

Tai, C. and J. J. Liu Tai. 2001. Future prospects of duck production in Asia. J. Poult. Sci. 38:99-112.

$\mathrm{Xu}$, G. F. and K. W. Chen. 2003. Photograph album of China indigeneous poultry breeds. Beijing, China Agricultural Press.

Yiu, X., C. X. Sheng, Q. N. Lin, D. L. Wang, G. Y. Wang, J. G. Wang, Q. X. Guang, Y. L. Yi, M. Y. Li, Y. L. Li, and T. J. Qiu. 1985. Atlas and Species Profile of Fujian Livestock and Poultry Breeds. Shan Ma ducks. Fujian Science and Technology Publishing House, Fuzhou, China, pp. 51-52. 